\title{
Isolation of Acetylene-reducing Spirilla from the Roots of Potamogeton filiformis from Loch Leven (Kinross)
}

\author{
By ROSEMARY SYLVESTER-BRADLEY* \\ Department of Microbiology, School of Agriculture, University of Edinburgh, \\ Edinburgh $\mathrm{EH} 9{ }_{3} J G$
}

(Received 22 March 1976; revised 10 June 1976)

\section{INTRODUCTION}

Significant levels of nitrogen-fixation, measured using ${ }^{15} \mathrm{~N}_{2}$, and/or acetylene reduction (Hardy et al., I968), occur on the roots of non-leguminous aquatic macrophytes (Patriquin \& Knowles, 1972; Bristow, 1974), and on the roots of rice seedlings growing in waterlogged soil (Dommergues et al., 1973). This activity is attributed to asymbiotic bacteria. Microaerophilic acetylene-reducing spirilla have been isolated from the roots of maize (von Bulow \& Dobereiner, 1975) and Digitaria decumbens (Day \& Dobereiner, 1976) plants in Brazil; these roots also showed high levels of nitrogenase activity by the acetylene-reduction method. The root zone of some aquatic macrophytes is known to be aerated via a channel of tissue (aerenchyma) through which air passes from the shoots to the roots (Armstrong, 1972). This enables the plants to grow in anaerobic sediment. The aerobic or semi-aerobic zone immediately around the roots is likely to be suitable for microaerophilic bacteria. In this study the roots of Potamogeton filiformis, one of the major aquatic macrophytes in Loch Leven, Kinross, Scotland (Jupp, Spence \& Britton, I974), were examined for the presence of nitrogen-fixing spirilla, and some characteristics of pure cultures of the organisms isolated from them were investigated.

\section{METHODS}

Basic medium. This contained: $0.4 \mathrm{~g} \mathrm{KH}_{2} \mathrm{PO}_{4} ; 0 . \mathrm{I} \mathrm{g} \mathrm{K}_{2} \mathrm{HPO}_{4} ; 0.2 \mathrm{~g} \mathrm{MgSO}_{4} .7 \mathrm{H}_{2} \mathrm{O}$; $0 . \mathrm{I} \mathrm{g} \mathrm{NaCl} ; 0.02 \mathrm{~g} \mathrm{CaCl}_{2} ; 0.0 \mathrm{I} \mathrm{g} \mathrm{FeCl}_{3} ; 0.002 \mathrm{~g} \mathrm{NaMoO}_{4} .2 \mathrm{H}_{2} \mathrm{O} ; 3.5 \mathrm{~g}$ (semi-solid) or I $5 \mathrm{~g}$ (pour plates) Difco Bacto Special Noble Agar; I 1 distilled water. The carbon and nitrogen sources added to this medium in different experiments are described below. All incubations were at $30^{\circ} \mathrm{C}$.

Preliminary enrichment cultures. Samples of $P$. filiformis roots $(0.5$ to $\mathrm{I} \cdot 0 \mathrm{~cm}$ long) were taken and, on the same day, were washed in lake water and placed in semi-solid medium ( $\mathrm{cm}$ deep in I oz vials) containing $0.5 \%$ sodium malate. After incubation for I day, the root pieces were removed and acetylene-reduction tests were carried out on the cultures.

Purification. Purification of acetylene-reducing cultures as described by von Bulow \& Dobereiner (1975) was not successful. Purification was achieved by mixing samples from preliminary enrichment cultures which reduced the most acetylene with $5 \mathrm{ml}$ sterile distilled water or buffered saline $(\mathrm{pH} 7.0$ ) for $5 \mathrm{~min}$; and then inoculating $0.1 \mathrm{ml}$ samples into pour plates containing $0.5 \%$ sodium malate and $0.05 \%$ yeast extract, and incubating for 7 days.

\footnotetext{
* Present address: Instituto Nacional de Pesquisas da Amazonia, Caixa Postal 478, 69000-Manaus-
} Amazonas, Brazil. 
Table I. Relative growth and acetylene reduction by five pure spirillum cultures in semi-solid media

Additions to basic nitrogen-free semi-solid medium*

Gas pha
Air
Air
Air
Air
Air
Air

Visible growth

$-\overline{+}$
+++
-
+
+

$2 \% \mathrm{O}_{2}$ in $\mathrm{N}_{2}$ $2 \% \mathrm{O}_{2}$ in $\mathrm{N}_{2}$
Acetylene reduction $\dagger$

0
80
0
0
0
0
60
80

2. Sodium malate $+\mathrm{VfC}$

* $0.5 \%$ Sodium malate; $0.5 \%$ glucose; $0.1 \%\left(\mathrm{NH}_{4}\right)_{2} \mathrm{NO}_{3} ; 0.05 \%$ Difco Bacto vitamin-free casamino acids (VfC).

$\dagger$ Average nmol ethylene produced per culture in I h. Variation within experiments was less than $5 \%$.

Single colonies were selected and inoculated into semi-solid medium containing $0.5 \%$ sodium malate and $0.05 \%$ yeast extract in I oz vials. After incubation for I day, cultures were assayed for acetylene reduction and those with the highest activity were selected. This dilution, plating and selection procedure was repeated two or three times and the final cultures were streaked on nutrient agar to test for purity.

Growth and acetylene reduction by purified cultures on various media. Washed suspensions of cells of five cultures grown in liquid medium containing $0.5 \%$ sodium malate and $0.1 \%\left(\mathrm{NH}_{4}\right)_{2} \mathrm{NO}_{3}$ were inoculated in triplicate into semi-solid media (I cm deep in $7.5 \mathrm{ml}$ vials capped with rubber seals) as shown in Table $\mathrm{I}$. To obtain $2 \%(\mathrm{v} / \mathrm{v}) \mathrm{O}_{2}$ in the gas phase, the bottles were flushed with nitrogen gas and $\mathrm{O}_{2}$ was added by syringe to $2 \%$. After incubation for $24 \mathrm{~h}$ the rate of acetylene reduction per culture was determined, and a relative estimate of growth was made visually.

Acetylene reduction. Rates of acetylene reduction were determined by adding acetylene to $10 \%(\mathrm{v} / \mathrm{v})$, incubating for $\mathrm{I}$ to $2 \mathrm{~h}$, and analysing the gas phase for ethylene in a Pye Unicam 104 gas chromatograph. Controls without acetylene contained no ethylene. Dilutions of pure ethylene were used to calibrate the gas chromatograph and the ethylene contamination of the acetylene was subtracted. The results were expressed as nmol ethylene produced per culture in I h (average), as it was not possible to enumerate cells in semi-solid cultures.

\section{RESULTS AND DISCUSSION}

All the initial enrichment cultures from the root pieces showed thin undulating pellicles of microbial growth I to $2 \mathrm{~mm}$ below the surface of the agar, and reduced acetylene after the root had been removed. Phase-microscopic examination revealed motile spiral-shaped organisms ( 2 to $3 \times 5$ to $10 \mu \mathrm{m}$ ) containing many refractile bodies. From these enrichment cultures five pure cultures of bacteria which consistently reduced acetylene were obtained. These cultures originated from samples of $P$. filiformis collected from five different sites in the loch. The bacteria were smaller than the organisms in the original enrichment cultures $(0.5$ to $\mathrm{r} .0 \times 3.0 \mu \mathrm{m})$, more motile, and did not contain refractile bodies. They had half to one spiral turn per cell and sometimes joined together to form spiral chains. They formed white opaque colonies in pour plates containing malate and yeast extract, and buff-coloured colonies on nutrient agar. They were Gram-negative. Of the Spirillum species described in 
Bergey's Manual of Determinative Bacteriology (1957), they were most closely related to Spirillum lipoferum.

Some characteristics of the spirilla in pure culture are shown in Table I. Under air at $30{ }^{\circ} \mathrm{C}$ they did not grow in completely nitrogen-free malate medium (medium I); but grew in a sub-surface pellicle and reduced acetylene vigorously in semi-solid malate medium containing $0.05 \%$ vitamin-free casamino acids (VfC) (medium 2). They did not grow in liquid medium 2. In semi-solid malate medium containing $0 . \mathrm{I} \%\left(\mathrm{NH}_{4}\right)_{2} \mathrm{NO}_{3}$ but no VfC (medium 3), they grew nearer the surface and did not reduce acetylene. They grew well in liquid medium 3 (although in wet mounts a microaerotactic response, as described by Wells \& Krieg (1965) for S. volutans, was observed). This apparent decrease in oxygen sensitivity and concomitant lack of acetylene reduction when grown in medium containing $\left(\mathrm{NH}_{4}\right)_{2} \mathrm{NO}_{3}$ was as expected for aerobic nitrogen-fixing bacteria: in other species, nitrogenase synthesis is inhibited by fixed nitrogen, and continuous cultures are very sensitive to oxygen when fixing nitrogen (Hill, Drozd \& Postgate, 1972).

Other organisms have been reported to require yeast extract or $\mathrm{VfC}$ in the growth medium in order to fix nitrogen from air. In Mycobacterium flavum $30 \mathrm{I}$ the need for yeast extract was eliminated by growing cultures at low oxygen tensions (Biggins \& Postgate, 1969). Hill (1975) found that with VfC at $2 \mathrm{mg} \mathrm{m}^{-1}$ all colonies of Klebsiella pneumoniae grown under air reduced acetylene, and suggested that $\mathrm{VfC}$ contains enough combined nitrogen to support growth until respiratory activity lowers the oxygen tension within the colony sufficiently to allow nitrogenase activity. Table $\mathrm{I}$ indicates a similar effect on the spirilla. When the oxygen tension over the semi-solid medium was reduced to $2 \%$, they grew and reduced acetylene in nitrogen-free medium almost as well as they did in medium containing $\mathrm{VfC}$. Thus, apparently, VfC is required to enable the spirilla grown under air to overcome oxygen toxicity, even when growing in a subsurface pellicle in semi-solid medium. This may be because nitrogen gas is less soluble than oxygen in water, and becomes limiting just below the surface of the agar; under air the bacteria would be forced to grow at superoptimal $\mathrm{PO}_{2}$ to obtain sufficient nitrogen.

The S. lipoferum isolated by Day \& Dobereiner (1976) grows under air on completely nitrogen-free semi-solid media, will grow on glucose, although not in nitrogen-free media, and forms a pink pigment in older cultures. The isolates described here do not grow on glucose with $\left(\mathrm{NH}_{4}\right)_{2} \mathrm{NO}_{3}$ under air (medium 4 ), and do not grow better on glucose plus VfC (medium 5) under air than can be explained by their growth on $\mathrm{VfC}$ alone (medium 6) (Table I). No pigment has been observed. Thus, although they are somewhat similar to the maize and Digitaria isolates, they differ in these properties and in the difficulty in isolating them by the method described by von Bulow \& Dobereiner (1975) and Day \& Dobereiner (1976). The nitrogen-fixing spirilla described by Becking (1963) did not grow in the absence of yeast extract and may have been the same as the isolates described here. These preliminary observations support the suggestion that there is more than one form of $S$. lipoferum.

Experiments described elsewhere (Sylvester-Bradley, 1976) have shown that washed $P$. filiformis roots from Loch Leven can reduce acetylene at an optimum oxygen concentration between 0 and $5 \%(\mathrm{v} / \mathrm{v})$ in the dark [average rates observed at lake temperature were up to $\left.90 \mathrm{nmol} \mathrm{C}_{2} \mathrm{H}_{2}(\mathrm{~g} \text { dry roots })^{-1} \mathrm{~h}^{-1}\right]$. Some of the acetylene-reducing activity described by Patriquin \& Knowles (1972) was also higher under aerobic than under anaerobic conditions. Thus it is possible that this activity is due to micro-aerophilic organisms. The absence of reports of nitrogen-fixing spirilla in aquatic systems and temperate climates may be due to the lack of methods for isolating them. Further investigations might reveal that they are of considerable ecological and economic significance. 
I gratefully acknowledge the collaboration of Dr J. Dobereiner at the initiation of this project, and the support of a NERC research studentship at the University of Edinburgh, supervised by Dr A. J. Holding.

\section{REFERENCES}

ARmStrong, W. (1972). A re-examination of the functional significance of aerenchyma. Physiologia plantarum 27, 173-177.

Becking, J. H. (1963). Fixation of molecular nitrogen by an aerobic Vibrio or Spirillum. Antonie van Leeuwenhoek 29, 326.

Biggins, D. R. \& Postgate, J. R. (I969). Nitrogen fixation by cultures and cell-free extracts of $M y c o-$ bacterium flavum 301. Journal of General Microbiology 56, I 8I-I93.

Bergey's Manual of Determinative Bacteriology, 7th edn (1957). Edited by R. S. Breed, E. G. D. Murray and N. R. Smith. London: Baillière, Tindall \& Cox.

BRISTOW, J. M. (1974). Nitrogen fixation in the rhizosphere of freshwater angiosperms. Canadian Journal of Botany 52, $217-221$.

Bulow, J. F. W. von \& Dobereiner, J. (1975). Potential for nitrogen fixation in maize genotypes in Brazil. Proceedings of the National Academy of Sciences of the United States of America 72, 2389-2393.

DAY, J. M. \& Dobereiner, J. (I976). Physiological aspects of $\mathrm{N}_{\mathbf{2}}$-fixation by a Spirillum from Digitaria roots. Soil Biology and Biochemistry 8, 45-50.

Dommergues, Y., Balandreau, J., Rinaudo, G. \& Weinhard, P. (I973). Non-symbiotic nitrogen fixation in the rhizospheres of rice, maize and different tropical grasses. Soil Biology and Biochemistry 5, 83-89.

Hardy, R. W. F., Holsten, R. D., JACKson, E. K. \& Burns, R. C. (I968). The acetylene-ethylene assay for nitrogen-fixation: laboratory and field evaluation. Plant Physiology 43, I I 85-1 207.

Hill, S. (1975). Acetylene reduction by Klebsiella pneumoniae in air related to colony dimorphism on low fixed nitrogen. Journal of General Microbiology 9r, 207-209.

Hill, S., Drozd, J. W. \& Postgate, J. R. (1972). Environmental effects on the growth of nitrogen-fixing bacteria. Journal of Applied Chemistry and Biotechnology 22, 54I-558.

Jupp, B. P., Spence, D. H. N. \& BRitton, R. H. (1974). The distribution and production of submerged macrophytes in Loch Leven, Kinross. Proceedings of the Royal Society of Edinburgh B74, I95-208.

PATRIQUin, D. \& KNowles, R. (1972). Nitrogen-fixation in the rhizosphere of marine angiosperms. Marine Biology 16, 49-58.

SYLVESTER-BRADLEY, R. (1976). Investigations into the measurement of nitrogen-fixation in fresh-water lake sediments. Ph.D. thesis, University of Edinburgh.

Wells, J.S. \& KRIEG, N. R. (I965). Cultivation of Spirillum volutans in a bacteria-free environment. Journal of Bacteriology $90,8 \mathrm{I} 7-8 \mathrm{I} 8$. 